\title{
Synanthropic triatomines (Hemiptera, Reduviidae) in the State of Pernambuco, Brazil: geographical distribution and natural Trypanosoma infection rates between 2006 and 2007
}

\author{
Triatomíneos sinantrópicos (Hemiptera, Reduviidae) no Estado de Pernambuco, Brasil: \\ distribuição geográfica e índices de infecção natural por Trypanosoma entre 2006 e 2007
} \begin{abstract}
Dayse Rocha $^{3}$, José Jurberg ${ }^{3}$ and Rodrigo Gurgel-Gonçalves ${ }^{4}$
\section{ABSTRACT}

Introduction: The present study shows a descriptive analysis of triatomine occurrence and its natural Trypanosoma infection rates in the state of Pernambuco, Brazil, between 2006 and 2007. Methods: Entomological data for the species, such as specimens captured in both intra and peridomiciles and natural infection index, were obtained via domiciliary capture in 147 municipalities from 11 Regional Managements of Health. The database was obtained from a sample of insects (100\% infected and $20 \%$ non-infected) sent to the Central Laboratory of Pernambuco. Results: A total of 18,029 triatomines were analyzed from 138 municipalities of the state. Triatoma pseudomaculata (35\%), Triatoma brasiliensis (34\%), and Panstrongylus lutzi (25\%) were the most captured species. These species also showed a widespread geographical distribution in the state. Panstrongylus megistus, Triatoma petrocchiae, Triatoma melanocephala, Triatoma sordida, Rhodnius nasutus, Rhodnius neglectus, and Triatoma infestans showed more limited geographical distribution and lower relative abundance. The parasitological research showed that $8.8 \%$ of the triatomines were naturally infected with flagellates morphologically similar to Trypanosoma cruzi and $91.3 \%$ of them were captured inside houses in 113 municipalities. P. lutzi showed the highest rates of natural infection. Conclusions: After the control of T. infestans, synanthropic species, such as T. brasiliensis, T. pseudomaculata, and $P$. lutzi, maintain the risk of T. cruzi transmission to humans in the state of Pernambuco. These species are widely distributed, and infected specimens have been found inside houses. Thus, an enhanced surveillance and vector control of Chagas disease is recommended in Pernambuco. Keywords: Triatominae. Vector surveillance. Chagas disease. Pernambuco. Brazil.
\end{abstract}

Maria Beatriz Araújo Silva ${ }^{1,2}$, Ana Virgínia Matos Sá Barreto ${ }^{1}$, Helker Albuquerque da Silva ${ }^{2}$, Cleber Galvão ${ }^{3}$,

\section{RESUMO}

Introdução: $O$ presente estudo apresenta uma análise descritiva da ocorrência de triatomíneos e seus índices de infecção natural por Trypanosoma no Estado de Pernambuco, entre 2006 e 2007. Métodos: Dados entomológicos para as espécies de triatomíneos, tais como espécimes capturados no intra e peridomicílio, e índice de infecção natural foram obtidos por meio da captura domiciliar em 147 municípios das 11 Gerências Regionais de Saúde. A pequisa foi baseada em uma amostra de insetos (100\% dos infectados e $20 \%$ dos não infectados) enviados para o Laboratório Central de Pernambuco. Resultados: No total, 18.029 triatomíneos foram analisados provenientes de 138 municípios. Triatoma pseudomaculata (35\%), Triatoma brasiliensis (34\%) e Panstrongylus lutzi (25\%) foram as espécies mais capturadas. Estas espécies também apresentaram ampla distribuição geográfica no estado. Panstrongylus megistus, Triatoma petrocchiae, Triatoma melanocephala, Triatoma sordida, Rhodnius nasutus, Rhodnius neglectus e Triatoma infestans apresentaram distribuição geográfica mais restrita e menores valores de abundância relativa. A pesquisa parasitológica mostrou que $8,8 \%$ dos triatomíneos estavam infectados por flagelados morfologicamente similares a Trypanosoma cruzi e $91,3 \%$ deles foram capturados no interior das habitações em 113 municípios. P. lutzi apresentou as maiores taxas de infecção natural. Conclusões: Após o controle do T. infestans, as espécies sinantrópicas T. brasiliensis, T. pseudomaculata e $P$. lutzi mantêm o risco de transmissão do T. cruzi ao homem no Estado de Pernambuco. Estas espécies são amplamente distribuídas e espécimes infectados foram encontrados dentro das casas. Assim, nossos resultados recomendam reforçar a vigilância e controle vetorial da doença de Chagas em Pernambuco.

Palavras-chaves: Triatominae. Vigilância vetorial. Doença de Chagas. Pernambuco. Brasil.

1. Laboratório Central de Saúde Pública, Secretaria Estadual de Saúde do Estado de Pernambuco, Recife, PE. 2. Faculdade de Enfermagem Nossa Senhora das Graças, Universidade de Pernambuco, Recife, PE. 3. Laboratório Nacional e Internacional de Referência em Taxonomia de Triatomíneos, Instituto Oswaldo Cruz, Fundação Oswaldo Cruz, Rio de Janeiro, RJ. 4. Laboratório de Parasitologia Médica e Biologia de Vetores, Faculdade de Medicina, Universidade de Brasília, Brasilia, DF.

Address to: Dra. Maria Beatriz Araújo Silva. LABEND/SES-PE. Av. Conde da Boa Vista 1.570, Boa Vista, 50640-040 Recife, PE, Brasil.

Phone: $55813184-3919$

e-mail: silvamba@yahoo.com.br

Received in 25/04/2011

Accepted in 17/06/2011

\section{INTRODUCTION}

Today, Chagas disease or American Trypanosomiasis continues to be a chronic and potentially fatal illness in Latin America ${ }^{1}$. According to estimates by the Pan American Health Organization, 20\% of Latin American population was at risk (109 million individuals), and nearly 7.7 million individuals were infected in 2005 (1.9 million in Brazil) ${ }^{2-3}$. The etiological agent, Trypanosoma cruzi (Chagas, 1909), is mainly transmitted by hematophagous insects of the subfamily Triatominae (Hemiptera, Reduviidae) adapted to colonize human dwellings ${ }^{4}$.

The estimated prevalence of human Chagas disease in the State of Pernambuco, Northeastern Brazil, in the 1980 s was $2.8 \%$, and seropositive people were detected in 144 of 163 municipalities 5 . In the 1990s, serological surveys showed that infections with T. cruzi still occur in the state ${ }^{6-7}$. According to the last national survey of Chagas disease seroprevalence carried out in Brazil between 2001 and 2008, four positive cases were detected in Pernambuco. One case involved a child below 5 years whose mother was also seropositive ${ }^{8}$.

Currently, the subfamily Triatominae contains 142 species, grouped into 18 genera and five tribes $^{9-12}$. In Brazil, there are 62 recognized species of Triatominae (Galvão and Gurgel-Gonçalves unpublished data). Pioneering studies on the vectors of Chagas disease in Pernambuco reported the occurrence of Triatoma infestans (Klug 1834) and other eight species ${ }^{13-15}$. Triatoma brasiliensis Neiva, 1911 and Triatoma pseudomaculata Corrêa \& Espinola, 1964 are the most captured triatomines among the 13 species registered in the State of Pernambuco ${ }^{7,16-17}$.

The occurrence of native triatomine species that sporadically invade or reinvade human dwellings is a major difficulty for the consolidation of vector control $^{18-19}$. Knowledge of geographical distribution and natural infection of these bugs is fundamental to 
the understanding of epidemiological aspects related to the T. cruzi transmission and should be considered to guide the actions of control and surveillance of Chagas disease. Thus, the aim of the present work was to analyze the geographical distribution of triatomines and their natural Trypanosoma infection in the State of Pernambuco, according to the Regional Managements of Health between 2006 and 2007.

\section{METHODS}

The state of Pernambuco is geographically situated in the northeast region of Brazil. According to the IBGE (Census 2010), this state is divided into 185 municipalities, covering an area of $98,146.315 \mathrm{~km}^{2}$, with a population of $8,796,448$ people. Eighty percent of the population is in urban areas (http://www.ibge.gov. $\mathrm{br} /$ estadosat/). Municipalities are distributed in five geographical regions: the metropolitan area of Recife (coastal region with mangrove and Atlantic rainforest), Zona da Mata (Atlantic rainforest), Agreste (area of transition between the Atlantic rainforest and the Caatinga), Sertão, and Sertão do São Francisco (areas of semi-arid Caatinga). All of them are operationally subordinated to eleven Regional Managements of Health (Gerência Regional de Saúde - GERES), Figure 1. Entomological data were obtained via domiciliary capture in 147 municipalities from 11 GERES of the State of Pernambuco between 2006 and 2007. During the conduct of this research, Afogados da Ingazeira and Serra Talhada were part of the same GERES, but in 2007, this GERES was divided (Figure 1).
Triatomines were collected manually by the agents of endemic diseases in the municipalities and sent to the GERES. The materials used for triatomine collection were metal tweezers and flashlights to inspect cracks and sites deprived of light, and, when necessary, dislodging liquid (Pirisa 2\%) was applied.

The database used in this study considered a sample of insects sent by the 11 GERES of the state to the Laboratory of Endemic Diseases, Central Laboratory of Pernambuco (LABEND/LACEN-PE). This laboratory was responsible for quality control (taxonomic identification and parasitological exams of triatomines) and helped in the surveillance activities. The database included all infected bugs and $20 \%$ of the negative bugs after laboratory examination in the GERES. Those insects were taken for a reexamination between January 2006 and December 2007. For the 2006 database, we considered the following entomological indicators: number of insects captured in the municipality (males, females, and nymphs) in both intra and peridomiciles and the number of infected bugs by flagellates morphologically similar to T. cruzi.

Triatomines were identified to the species level according to Lent and Wygodzinsky ${ }^{4}$. The parasitological research was conducted through abdominal compression of triatomines and subsequent examination of fresh feces. The phenotypic identification of the parasites was made by observation under a microscope of Giemsastained insect feces. The natural infection rate was obtained from the ratio between the number of infected insects and the number of insects examined $\times 100^{20}$.

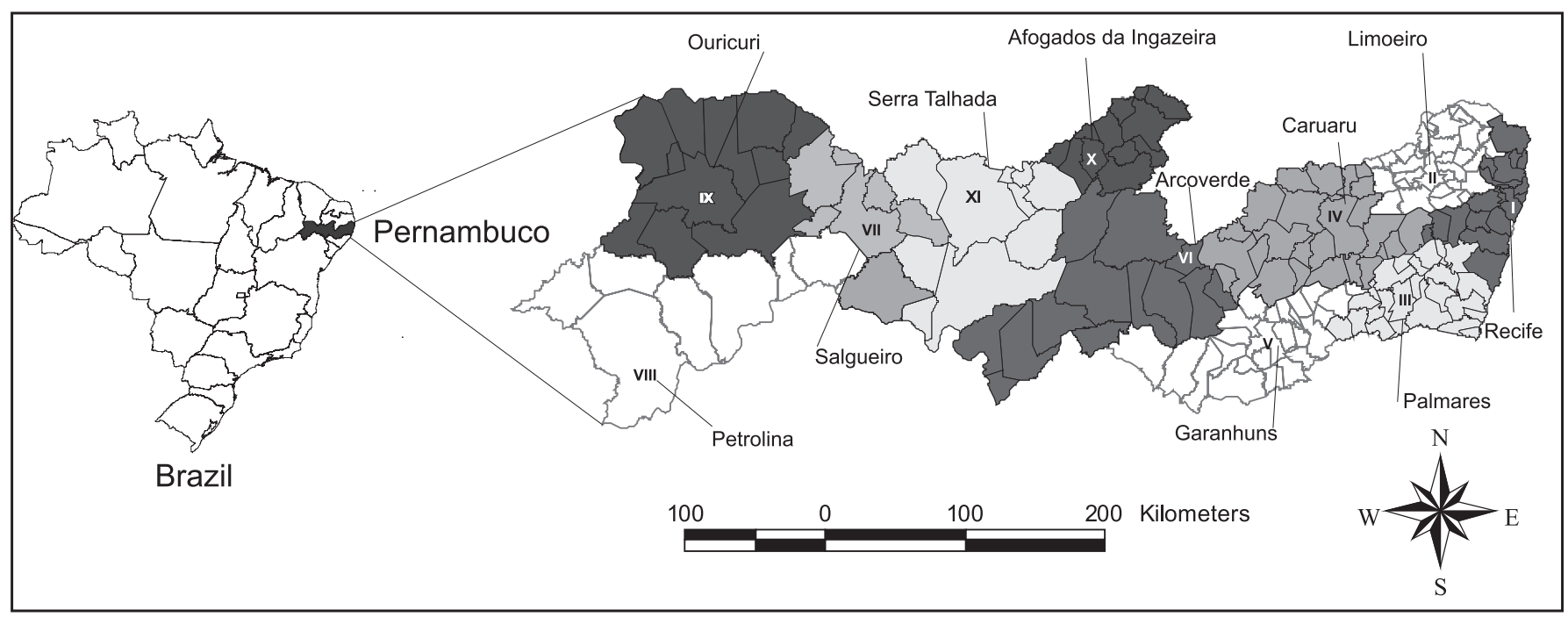

FIGURE 1 - Location of the State of Pernambuco in Brazil and its 11 Regional Managements of Health (GERES). The numbers indicate the municipality administrative center of each GERES.

\section{RESULTS}

A total of 18,029 triatomines were analyzed from 138 municipalities of the state between 2006 and 2007. The 10 identified species were: Triatoma pseudomaculata, Triatoma brasiliensis, Panstrongylus lutzi (Neiva and Pinto, 1923), Panstrongylus megistus (Burmeister, 1835), Triatoma petrocchiae Pinto \& Barreto, 1925, Triatoma melanocephala Neiva and Pinto, 1923, Triatoma sordida (Stål, 1859), Triatoma infestans, Rhodnius nasutus Stål, 1859 and Rhodnius neglectus Lent, 1954.

Triatoma pseudomaculata (35\%), T. brasiliensis (34\%), and P. lutzi (25\%) were the most captured species considering the sample of insects examined. These species also showed a widespread geographical distribution in the state. The other species showed more limited geographical distribution and lower relative abundance (Figure 2). The parasitological research showed that $8.8 \%$ of the triatomines were naturally infected with flagellates morphologically similar to Trypanosoma cruzi, and $91.3 \%$ of them were captured inside houses in 113 municipalities. T. melanocephala and $P$. lutzi showed the highest rates of natural infection (Table 1). However, T. melanocephala had a little representation in the sample analyzed.

The geographical distribution and relative abundance of triatomine species captured at 11 GERES are shown in Figure 2. Details about the occurrence and natural infection of these species in each region are listed below. 


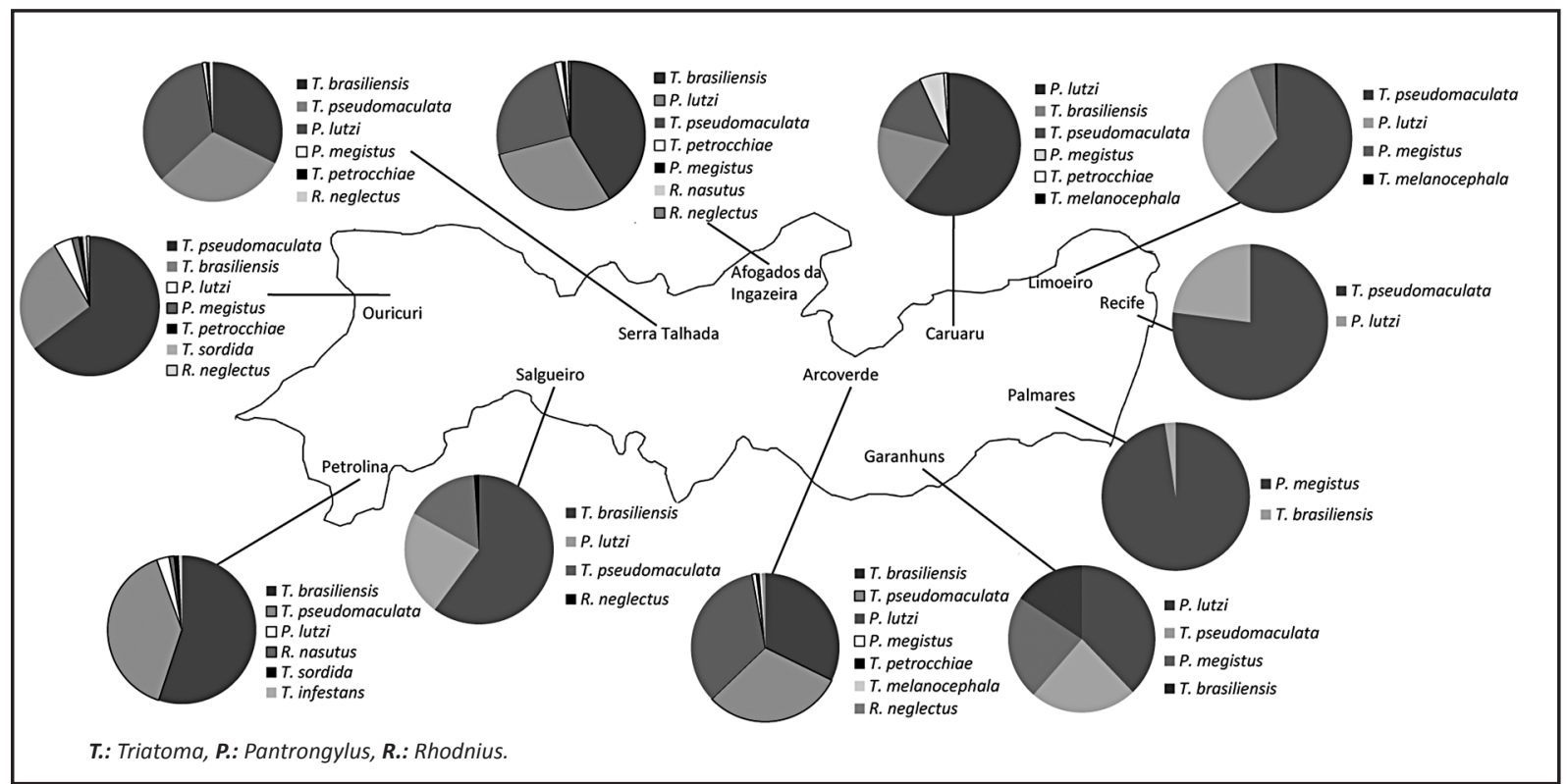

FIGURE 2 - Geographical distribution and relative abundance of 10 triatomine species triatomines recorded in 11 Regional Managements of Health (GERES) of the State of Pernambuco, Brazil, between 2006 and 2007.

\begin{tabular}{|c|c|c|c|c|c|c|c|c|c|}
\hline Species & Total collected & Intradomicile & Peridomicile & Nymphs & Males & Females & Examined & \multicolumn{2}{|c|}{ Infected } \\
\hline Triatoma brasiliensis & 2,998 & 2,106 & 892 & 648 & 1,099 & 1,251 & 2,996 & 195 & 6.5 \\
\hline Triatoma pseudomaculata & 2,900 & 1,821 & 1,079 & 393 & 1,387 & 1,120 & 2,888 & 232 & 8.0 \\
\hline Pantrongylus megistus & 504 & 413 & 91 & 76 & 203 & 225 & 502 & 58 & 11.6 \\
\hline Triatoma petrocchiae & 21 & 21 & 0 & 0 & 15 & 6 & 21 & 0 & 0.0 \\
\hline Triatoma sordida & 15 & 5 & 10 & 11 & 4 & 0 & 15 & 0 & 0.0 \\
\hline Triatoma melanocephala & 10 & 10 & 0 & 0 & 5 & 5 & 10 & 3 & 30.0 \\
\hline Total & 8,273 & 6,130 & 2,143 & 1,140 & 4,009 & 3,124 & 8,244 & 810 & 9.8 \\
\hline
\end{tabular}

\section{GERES I — Recife}

This GERES includes the Metropolitan Region of Recife and other 18 municipalities. Between 2007 and 2007, 16 municipalities did not send bugs to control quality in LABEND. Chagas disease vectors were found in two municipalities (Vitória and Pombos). By the time of this research, a total of 215 specimens of T. pseudomaculata and P. lutzi were examined with predominance of the first (Figure 2). In relation to the place of capture, $92.2 \%$ were found inside houses. Adults and nymphs of T. pseudomaculata were recorded, but only adult specimens of P. lutzi were captured. No triatomine was found infected in this GERES.

\section{GERES II — Limoeiro}

This GERES is composed of 31 municipalities located in the northern Zona da Mata, and 22 (71\%) of them were positive for four species: Panstrongylus lutzi, T. pseudomaculata, T. melanocephala, and P. megistus. A total of 2.667 triatomines were examined. T. pseudomaculata was predominant in this GERES (Figure 2). The majority of the insects (96.7\%) were found inside houses. Nymphs of all species were captured in this GERES, except T. melanocephala. Infected triatomines were found in 19 municipalities.

\section{GERES III - Palmares}

It is composed of 22 municipalities located in the southern Zona da Mata region. However, 18 municipalities did not send bugs to LABEND. Panstrongylus megistus was the main species among the 180 triatomines captured (Figure 2) in four municipalities (Quipapá, São Benedito do Sul, Belém de Maria e Lagoa dos Gatos) especially inside domiciles $(87.3 \%)$ where adults and nymphs were found. No triatomine was found infected in this GERES.

\section{GERES IV - Caruaru}

This GERES is located in the northern Agreste region, and 30 out of 32 municipalities surveyed were positive for triatomines. Six triatomine species were detected, mainly P. lutzi (Figure 2). A total of 1,578 specimens were captured ( $92.4 \%$ of them inside houses). Nymphs, males, and females of P. lutzi, T. pseudomaculata, and T. brasiliensis were collected. For other species, only adult specimens were collected. By the time of the study, 293 triatomines were infected in 16 municipalities.

\section{GERES V - Garanhuns}

This GERES is composed of 21 municipalities located in the southern Agreste region, and 20 of them registered the presence 
of vectors. Four species were detected (Figure 2). A total of 1,171 specimens were captured (92.4\% of them inside houses). Nymphs of T. pseudomaculata and P. lutzi were not registered. Infected triatomines were found in 18 municipalities.

\section{GERES VI - Arcoverde}

Triatoma pseudomaculata, T. brasiliensis, and P. lutzi were the most captured species in all the 13 municipalities that compose this GERES, located in the Sertão region. A total of 2,531 specimens were captured; $80.9 \%$ of them were found inside houses with predominance of T. brasiliensis (Figure 2). Nymphs of T. brasiliensis and T. pseudomaculata were captured. Infected bugs were detected in 10 municipalities.

\section{GERES VII — Salgueiro}

Triatomines were captured in all 7 municipalities that compose this GERES, which is located in the Sertão region. Triatoma brasiliensis predominated among the four species detected(Figure 2). Exceptionally, the presence of Rhodnius neglectus was detected (two non-infected males inside domicile). Most of the 992 (94.8\%) triatomines captured were found inside domiciles. Infected bugs were detected in 6 municipalities.

\section{GERES VIII — Petrolina}

Triatomines were captured in 6 out of the 7 municipalities of this GERES located in the Sertão do São Francisco region. This region presented a different profile in relation to the site of capture; $65 \%$ of all triatomines were found in the peridomiciles, totaling 1,974 specimens with predominance of Triatoma brasiliensis (Figure 2). Another peculiarity of this region was the presence of two species not detected in other GERES during the development of this work (Rhodnius nasutus and Triatoma infestans). Infected bugs were detected in 3 municipalities. Triatoma infestans specimens were captured inside houses in one municipality (Lagoa Grande), but they were not infected.

\section{GERES IX - Ouricuri}

Triatomines were captured in all the 11 municipalities that compose this GERES, located in the Sertão region. Similar to GERES VIII, there was a predominance of triatomines in peridomiciles (79.2\% of the 1,967 captured triatomines). Triatoma pseudomaculata (Figure 2) was the most captured species. As observed in GERES VIII, Triatoma sordida occurred rarely. Infected bugs were detected in 10 municipalities.

\section{GERES $X$ and GERES XI - Afogados da Ingazeira and Serra Talhada}

Triatomines were captured in all the 22 municipalities that compose these GERESes, located in the Sertão region. Seven species were detected (Figure 2), and a total of 1,730 specimens were captured from both GERESes in 2006. In 2007, after the separation of these two GERESes, 1,929 triatomines were captured in Afogados da Ingazeira and 1,071 in Serra Talhada. T. brasiliensis predominated among the seven species found, and co-occurrence of $R$. neglectus and R. nasutus was detected in Afogados da Ingazeira (Figure 2). Most of the triatomines $(82.9 \%)$ captured were found inside domiciles. Infected bugs were detected in 20 municipalities.

\section{DISCUSSION}

Pioneering studies on the epidemiology of Chagas disease in Pernambuco carried out in the $1950 \mathrm{~s}^{13}$ reported ecological aspects of seven species of triatomines: P. megistus, P. lutzi, Triatoma rubrofasciata (De Geer, 1773), T. pseudomaculata, T. sordida, T. brasiliensis, and T. melanocephala. Later, Psammolestes tertius Lent and Jurberg, 1965 and Triatoma infestans were recorded ${ }^{14,21}$. Triatomine surveys carried out in the 1970s and 1980s recorded three more species in the state: Triatoma tibiamaculata (Pinto, 1926), R. nasutus, and R. neglectus ${ }^{15-16}$. Dias et al. ${ }^{7}$ included T. petrocchiae in the list of 13 recognized species of triatomines in the State of Pernambuco. Differently from what was observed by Dias et al. ${ }^{7}$, our study did not detect these 3 species: Psammolestes tertius, T. tibiamaculata, and T. rubrofasciata. The first species occurs frequently in bird nests of the family Furnariidae ${ }^{22}$ with a wide distribution in the State of Pernambuco ${ }^{23}$. However, records of this species in domestic environments are rare, and although the species has already been experimentally infected with T. cruzi, natural infection is not frequent, due to a marked ornithophily. To our knowledge, T. tibiamaculata was recorded in Bonito (GERES IV) ${ }^{16}$, and the occurrence of T. rubrofasciata has been recorded since 1950s in Recife ${ }^{13}$.

As observed by Dias et al. ${ }^{7}$, T. brasiliensis and T. pseudomaculata remain as the main species caught in the State of Pernambuco. In the present study, these insects were often found inside houses, both in semi-arid Caatinga and in the Zona da Mata. Triatoma brasiliensis is considered the main vector of T. cruzi in northeastern Brazil ${ }^{17}$. In the wild environment, this species is often found under rocks, developing colonies associated with rodents (Kerodon rupestris) with high rates of infection with T. cruzi ${ }^{24}$. Our results showed that T. brasiliensis has a wide geographical distribution in the State of Pernambuco and it was one of the main species caught between 2006 and 2007. According to Costa et al. ${ }^{25}$, the State of Pernambuco includes hybrid zones of members of T. brasiliensis complex, and biological, morphological, ecological and genetic studies of populations of this complex should be developed in these areas. Unlike T. brasiliensis, specimens of T. pseudomaculata live under bark of dead trees and bird nests ${ }^{26}$. The species is most frequent in the peridomiciles, usually feeds on birds $^{27}$ and has lower rates of infestation, colonization, and infection ${ }^{7}$. However, Assis et al. ${ }^{28}$ suggest that the increasing presence of T. pseudomaculata in household environments is related to climate change, deforestation, and expansion of agricultural areas. Moreover, the known ability of dispersal by flight guided by artificial light of T. pseudomaculata and T. brasiliensi ${ }^{29}$ favors the invasion of households in the northeastern region of Brazil.

The epidemiological importance of $P$. lutzi is increasing in the State of Pernambuco. According to Lucena ${ }^{13}$, only seven adult specimens of $P$. lutzi were recorded among the 15,653 captured triatomines in the state in a survey conducted in the 1950s. The same author indicated a low synanthropic potential of this species, considering its rare presence in the households and even the absence of nymphs. According to Costa et al. ${ }^{17}, P$. lutzi was the fifth most common species by analyzing the number of triatomine captures in 12 Brazilian states in 1998 (2,900 specimens captured). Moreover, Silveira and Dias $^{30}$ indicated an increase in the number of $P$. lutzi specimens captured in Brazil, especially in the State of Pernambuco over the past 30 years. Our results showed that $P$. lutzi was the third most abundant species in Pernambuco, with a wide geographical 
distribution and high Trypanosoma infection rate. These resultsillustrate the increasing epidemiological importance of $P$. lutz $i$ in recent years. This species, occurs in armadillo burrows in semi-arid Caatinga ${ }^{31}$ but feeds on different animals in the domestic environment, and has high rates of infection $^{32}$.In Pernambuco, P. lutzimaintains the risk of T.cruzitransmission to humans due to frequent invasion of infected adults in the houses.

Triatoma melanocephala and P. megistus also had high rates of natural infection; however, they occurred more frequently in the Zona da Mata, especially in Palmares and Limoeiro GERESes, in areas with higher humidity and lower temperature, in agreement with pioneering observations of Lucena ${ }^{13}$. Specimens of $P$. megistus live in hollow trees in arboreal habitats ${ }^{26}$ where they usually feed on marsupials (Didelphis spp.), which are often infected with T. cruzi, thus justifying the high rates of infection. A similar process must occur with T. melanocephala, but the habitats and food sources of this species are poorly known ${ }^{26}$. Future studies may clarify ecological and biological potential of T. melanocephala in the transmission of T. cruzi.

Triatoma petrocchiae was widespread in Pernambuco, but few specimens were collected. Furthermore, no nymphs were captured in household environments, and the insects examined were not infected by Trypanosoma, suggesting a low vector competence. Although T. sordida is the most captured species in Brazil ${ }^{7,17}$, in Pernambuco, its occurrence was limited to Ouricuri and Petrolina GERESes. Few specimens of $T$. sordida were captured in these areas, and none was infected, which indicates a low risk of $T$. cruzi transmission. This can be explained by its peridomestic behavior, as well as by its marked ornithophily and low rates of natural infection ${ }^{7,17,33}$.

The low occurrence of T. infestans in Pernambuco detected in the present study is another evidence of the probable elimination of this species in the state due to control campaigns ${ }^{30,34}$. However, the residual focus ( 2 specimens in houses from the municipality of Lagoa Grande, Petrolina GERES) indicates the importance of continued entomological surveillance to avoid a re-infestation by this species.

The presence of Rhodnius in the State of Pernambuco has been registered since the $1970 \mathrm{~s}^{15-16}$. In the present study, $R$. neglectus occurred in five GERESes located in semi-arid regions of Sertão and Sertão do São Francisco, while R. nasutus was registered only in GERES Petrolina. No specimen was found infected by Trypanosoma, and no nymphs of these species were captured in domestic environments. Rhodnius neglectus and R. nasutus occur predominantly in the wild environment, inhabiting different palm species in Brazil ${ }^{35}$.

Rhodnius neglectus has a wide geographical distribution in Brazil, occurring mainly in the Cerrado and transition areas with other biomes ${ }^{36}$. Rhodnius nasutus predominates in the Caatinga in the northeast region in different tree species, especially palm trees ${ }^{37-38}$; however, this triatomine can colonize different peridomestic ecotopes as shown by Sarquis et al. ${ }^{39}$. Despite these differences, the co-occurrence of $R$. neglectus and $R$. nasutus in some states in the Northeast Brazil, including Pernambuco, was predicted ${ }^{40}$. Our results confirm these predictions and reinforce the idea that the identification of these species in these areas must be made with the aid of morphometric $\mathrm{c}^{4-42}$ and molecular methods ${ }^{43}$ due to morphological similarities between these species. Finally, the sporadic occurrence of these species of Rhodnius in Pernambuco should be associated with the presence of palm trees in the peridomiciles.

We conclude that the risk of vector transmission of T. cruzi to humans still exists in the State of Pernambuco, as synanthropic triatomines were captured in 138 of the 185 existing municipalities, and in 113 of them, specimens infected with flagellates morphologically similar to T. cruzi were detected. The results show that of the 10 triatomine species recorded in the domestic environment between 2006 and 2007, Triatoma pseudomaculata, T. brasiliensis, and P. lutzi are the most relevant species for the epidemiological surveillance activities of Chagas disease in the State of Pernambuco after the control of T. infestans. In this scenario, strengthening entomological surveillance is recommended, with the routine of house visitation by health agents, community involvement encouragement with educational strategies, chemical control, and house improvement in the municipalities of the State of Pernambuco, to reduce the chances of developing domiciliary triatomine colonies.

\section{ACKNOWLEDGMENTS}

We thank Márcio Vinhaes for reviewing the manuscript. We are also grateful to LACEN for providing the database.

\section{CONFLICT OF INTEREST}

The authors declare that there is no conflict of interest.

\section{FINANCIAL SUPPORT}

Secretaria de Vigilância de Saúde (SVS) and Conselho Nacional de Desenvolvimento Científico e Tecnológico (CNPq).

\section{REFERENCES}

1. Coura JR, Viñas PA. Chagas disease: a new worldwide challenge. Nature 2010; 465:56-57.

2. Organizacion Panamericana de la Salud. Estimacion cuantitativa de la enfermedad de Chagas en las Americas. Montevideo, Uruguay: Organizacion Panamericana de la Salud; 2006.

3. Rassi Jr A, Rassi A, Marin-Neto JA. Chagas disease. Lancet 2010; 375:1388-1402.

4. Lent H, Wygodzisnky P. Revision of the Triatominae (Hemiptera, Reduviidae) and their significance as vectors of Chagas' disease. Bull Am Mus Nat Hist $1979 ; 163: 123-520$.

5. Camargo ME, Silva JR, Castilho EA, Silveira AC. Inquérito sorológico da prevalência da infecção chagásica no Brasil, 1975-1980. Rev Inst Med Trop S Paulo 1984; 26:192-204.

6. Tachibana H, Paz KC, Landivar WH, Kobayashi S, Montenegro LT, Figuerêdo-Silva J, et al. Survey for Trypanosoma cruzi infection in a municipality in northeast Brazil. Tokai J Exp Clin Med 1999; 24:131-136.

7. Dias JCP, Machado EMM, Fernandes AL, Vinhaes MC. Esboço geral e perspectivas da doença de Chagas no Nordeste do Brasil. Cad Saude Publica 2000; $16: 13-34$.

8. Ostermayer AL, Passos ADC, Silveira AC, Ferreira AW, Macedo V, Prata AR. $\mathrm{O}$ inquérito nacional de soroprevalência de avaliação do controle da doença de Chagas no Brasil (2001-2008). Rev Soc Bras Med Trop 2011; 44 (supl II):108-121.

9. Frías-Lasserre D. A new species and karyotype variation in the bordering distribution of Mepraia spinolai (Porter) and Mepraia gajardoi Frías et al (Hemiptera: Reduviidae: Triatominae) in Chile and its parapatric model of speciation. Neotropical Entomology 2010; 39: 572-583.

10. Galvão C, Carcavallo R, Rocha DS, Jurberg J. A checklist of the current valid species of the subfamily Triatominae Jeannel, 1919 (Hemiptera, Reduviidae) and their geographical distribution, with nomenclatural and taxonomic notes. Zootaxa 2003; 202:1-36.

11. Forero D, Weirauch C, Baena M. Synonymy of the Reduviidae (Hemiptera: Heteroptera) genus Torrealbaia (Triatominae) with Amphibolus (Harpactorinae), with notes on Amphibolus venator (Klug, 1830). Zootaxa 2004; 670:1-12. 
12. Schofield CJ, Galvão CJ. Classification, evolution, and species groups within the Triatominae. Acta Trop 2009; 110:88-100.

13. Lucena DT. Epidemiologia da doença de Chagas em Pernambuco. II - Notas sobre as espécies de Triatomíneos. Rev Bras Malariol Doencas Trop 1958; 10:355-368.

14. Dobbin Jr JE, Cruz AE. Sobre o encontro do Triatoma infestans (Klug) em Pernambuco. Rev Bras Malariol Doencas Trop 1967; 19:351-352.

15. Lucena DT, Lima-Borba H. Panstrongylus megistus leucofasciatus Lucena, 1950 and Rhodnius nasutus Stal, 1859 (Hemiptera: Triatominae), in Pernambuco, Brazil. Rev Inst Med Trop S Paulo 1977; 19:332-334.

16. Silveira AC, Feitosa VR, Borges R. Distribuição de triatomíneos capturados no ambiente domiciliar, no período 1975/83, Brasil. Rev Bras Malariol Doenças Trop 1984; 36:15-312.

17. Costa J, Almeida CE, Dotson EM, Lins A, Vinhaes M, Silveira AC, Beard CB. The epidemiologic importance of Triatoma brasiliensis as a Chagas disease vector in Brazil: a revision of domiciliary captures during 1993-1999. Mem Inst Oswaldo Cruz 2003; 98:443-449.

18. Guhl F, Pinto N, Aguilera G. Sylvatic triatominae: a new challenge in vector control transmission Mem Inst Oswaldo Cruz 2009; 104 (supl 1):71-75.

19. Silveira AC. Os novos desafios e perspectivas futuras do controle. Rev Soc Bras Med Trop 2011; 44 (supl II):122-124.

20. Silveira AC, Sanches O. Guia para amostragem aplicada a atividades de vigilância e controle vetorial da doença de Chagas. Organização Pan Americana de Saúde; 2003.

21. Lucena DT, Lucena NT. Psammolestes coreodes Bergroth, 1911 (Hemiptera, Reduviidae) em Pernambuco, Brasil. Rev Inst Med Trop S Paulo 1965; 7:160-168.

22. Gurgel-Gonçalves R, Cuba CAC. Infestation of thornbird nests (Passeriformes: Furnariidae) by Psammolestes tertius (Hemiptera: Reduviidae) across Brazilian Cerrado and Caatinga ecoregions. Zoologia 2011; 28:411-414

23. Gurgel-Gonçalves R, Silva RB. Analysis of the geographical distribution of Psammolestes Bergroth (Heteroptera: Reduviidae) in South America with new records of Psammolestes tertius Lent \& Jurberg. Zootaxa 2009; 2033:41-48.

24. Costa J, Almeida JR, Brito C, Duarte R, Marchon-Silva V, Pacheco R. Ecotopes, natural infection and trophic resources of Triatoma brasiliensis (Hemiptera, Reduviidae, Triatominae). Mem Inst Oswaldo Cruz 1998; 93:7-13.

25. Costa J, Peterson AT, Dujardin JP. Morphological evidence suggests homoploid hybridization as a possible mode of speciation in the Triatominae (Hemiptera: Heteroptera: Reduviidae). Infect Genet Evol 2009; 9:263-270.

26. Carcavallo RU, Rodríguez MEF, Salvatella R, Curto-Casas SI, Sherlock I, Galvão C, et al. Habitats and related fauna. In: Carcavallo RU, Galíndez Girón I, Jurberg J, Lent H, editors. Atlas of Chagas Disease Vectors in Americas. Vol II. Rio de Janeiro: Editora FIOCRUZ; 1998. p. 561-600.

27. Freitas SPC, Lorosa ES, Rodrigues DCS, Freitas ALC, Gonçalves TCM. Fontes alimentares de Triatoma pseudomaculata no Estado do Ceará, Brasil. Rev Saúde Pública 2005; 39: 27-32.

28. Assis GFM, Azeredo BVM, Carbajal de la Fuente AL, Diotaiuti L, Lana M. Domestication of Triatoma pseudomaculata (Côrrea \& Espínola 1964) in the Jequitinhonha Valley of the State of Minas Gerais. Rev Soc Bras Med Trop 2007; 40:391-396.

29. Carbajal de La Fuente A, Minoli SA, Lopes CM, Noireau F, Lazzari CR, Lorenzo MG. Flight dispersal of the Chagas Disease Vectors Triatoma brasiliensis and Triatoma pseudomaculata in Northeastern Brazil. Acta Trop 2007; 1001:115-119.

30. Silveira AC, Dias JCP. O controle da transmissão vetorial. Rev Soc Bras Med Trop 2011; 44: (supl II):52-63.

31. Dias-Lima AG, Menezes D, Sherlock I, Noireau F. Wild habitat and fauna of Panstrongylus lutzi (Reduviidae: Triatominae).J Med Entomol 2003; 40: 989-990.

32. Caranha L, Lorosa ES, Rocha DS, Jurberg J, Galvão C. Estudo das fontes alimentares de Panstrongylus lutzi (Neiva \& Pinto, 1923) (Hemiptera: Reduviidae: Triatominae) no Estado do Ceará. Rev Soc Bras Med Trop 2006; 39:347-351.

33. Diotaiuti L, Azeredo BVM, Busek SCU, Fernandes AJ. Controle do Triatoma sordida no peridomicilio rural do município de Porteirinha, Minas Gerais, Brasil. Pan Am J Public Health 1998; 3:21-25.

34. Dias JCP. Southern Cone Initiative for the elimination of domestic populations of Triatoma infestans and the interruption of transfusion Chagas disease: historical aspects, present situation, and perspectives. Mem Inst Oswaldo Cruz 2007; 102:11-18.
35. Abad-Franch F, Monteiro FA, Jaramillo NO, Gurgel-Gonçalves R, Dias FBS, Diotaiuti L. Ecology, evolution, and the long-term surveillance of vector-borne Chagas disease: A multi-scale appraisal of the tribe Rhodniini (Triatominae). Acta Trop 2009; 112:159-177.

36. Gurgel-Gonçalves R, Cuba CAC. Predicting the potential geographical distribution of Rhodnius neglectus (Hemiptera, Reduviidae) based on ecological niche modeling. J Med Entomol 2009; 46:952-960.

37. Dias FBS, Bezerra CM, Machado EMM, Casanova C, Diotaiuti L. Ecologica aspects of Rhodnius nasutus Stål, 1859 (Hemiptera: Reduviidae: Triatominae) in palms of the Chapada do Araripe in Ceará, Brazil. Mem Inst Oswaldo Cruz 2008; 103:824-830.

38. Lima MM, Sarquis O. Is Rhodnius nasutus (Hemiptera; Reduviidae) changing its habitat as a consequence of human activity? Parasitol Res 2008; 102:797-800.

39. Sarquis O, Sposina R, Oliveira TG, Mac Cord JR, Cabello PH, Borges-Pereira J, et al. Aspects of peridomiciliary ecotopes in rural áreas of Northeastern Brazil associated to triatominae (Hemiptera, Reuviidae) infestation, vectors of Chagas disease. Mem Inst Oswaldo Cruz 2006; 101:143-147.

40. Batista TA, Gurgel-Gonçalves R. Ecological niche modelling and differentiation between Rhodnius neglectus Lent, 1954, and R. nasutus Stål, 1859 (Hemiptera, Reduviidae, Triatominae), in Brazil. Mem Inst Oswaldo Cruz 2009 , 104:1165-1170.

41. Gurgel-Gonçalves R, Abad-Franch F, Ferreira JBC, Santana DB, Cuba CAC. Is Rhodnius prolixus (Triatominae) invading houses in central Brazil? Acta Trop 2008; 107:90-98.

42. Gurgel-Gonçalves R, Ferreira JBC, Rosa AF, Bar ME, Galvão C. Geometric morphometrics and ecological niche modelling for delimitation of nearsibling triatomine species. Med Vet Entomol 2011; 25:84-93.

43. Abad-Franch F, Monteiro FA. Molecular research and the control of Chagas disease vectors. An Acad Bras Ciênc 2005; 77:437-454. 